Notes

\title{
LINKING THE CULPABILITY AND CIRCUMSTANTIAL EVIDENCE REQUIREMENTS FOR THE SPOLIATION INFERENCE
}

\author{
DREW D. DROPKIN
}

\section{INTRODUCTION}

In the summer of 1989, Donald Vodusek, Sr., fueled his boat for a family trip from Pasadena, Maryland, to Baltimore's inner harbor. ${ }^{1}$ Approximately thirty minutes after he siphoned gas into the cabin cruiser in preparation for departure, Vodusek turned on the boat's bilge pump. ${ }^{2}$ Tragically, the boat exploded. ${ }^{3}$ Vodusek suffered secondand third-degree burns and died three months later due to burnrelated complications. ${ }^{4}$

Shirley Vodusek, Donald's wife, filed suit in federal district court $^{5}$ against the boat's manufacturer, Bayliner Marine Corporation, and the retail dealer of the boat, Stammer's Marine Center, Inc., alleging that a faulty bilge pump switch ignited vapors from a leaky fuel system to cause the fatal explosion. ${ }^{6}$ Vodusek retained Douglas Halsey, an expert in marine vessel safety, to examine the boat and to present testimony supporting Vodusek's theory. ${ }^{7}$ During the pretrial

\footnotetext{
Copyright (C) 2002 by Drew D. Dropkin.

1. Vodusek v. Bayliner Marine Corp., 71 F.3d 148, 151 (4th Cir. 1995).

2. $I d$.

3. $I d$.

4. Id.

5. The district court's decision in Vodusek was unpublished, and the synopsis of the underlying facts provided in this Note draws entirely from the summary of the facts provided by the court of appeals.

6. Vodusek, 71 F.3d at 151.

7. Id. at 155 .
} 
examination of the boat,

"Mr. Halsey and the Vodusek boys virtually attacked the boat with a chain saw and sledge hammer. The area which is critical to the theory eventually presented by Mr. Halsey[ ] was literally ripped apart. The integrity of the structure was violated....

... Mr. Halsey's activity made it impossible for his own theory to be verified or for the Defendants to make a full and fair inspection to develop alternative theories based on the evidence."

The defendants asked the court to rectify their inability to examine the boat. ${ }^{9}$ In response to their request, the district court issued the following instruction:

"[I]t is the duty of a party, a party's counsel and any expert witness, not to take action that will cause the destruction or loss of relevant evidence where that will hinder the other side from making its own examination and investigation of all potentially relevant evidence.

If you find in this case [that] the plaintiff's counsel and agents, including Mr. Halsey, failed to fulfill this duty, then ... you are permitted to, if you feel justified in doing so, assume that evidence made unavailable to the defendants by acts of plaintiff's counsel or agents, including Mr. Halsey, would have been unfavorable to the plaintiff's theory in this case."

The jury returned a verdict in favor of Bayliner Marine and Stammer's Marine Center, ${ }^{11}$ and the United States Court of Appeals for the Fourth Circuit affirmed the decision. ${ }^{12}$

In Vodusek v. Bayliner Marine Corp., the district court confronted the shockingly pervasive problem of spoliation of evidence. ${ }^{13}$ Spoliation occurs when a party destroys, mutilates, alters, or conceals relevant evidence. ${ }^{14}$ When evidence is spoliated, courts are called

8. Id. (quoting the district court's unpublished opinion).

9. Id.

10. Id. (quoting the district court's unpublished opinion).

11. Id. at 152 .

12. $I d$.

13. For a discussion of the prevalence of spoliation in civil litigation, see infra notes $24-34$ and accompanying text.

14. Black's LaW Dictionary 1409 (7th ed. 1999); Kathleen Kedigh, Spoliation: To the Careless Go the Spoils, 67 UMKC L. REV. 597, 598 (1999). 
upon to fashion a remedy for the nonspoliating party. ${ }^{15}$ Although this remedy may take many forms, ${ }^{16}$ one prominent and oft-employed judicial response is the issuance of a jury instruction that mirrors the instruction in Vodusek: if a party has failed to preserve potentially relevant evidence, the jury may infer that the evidence was destroyed because the evidence was adverse to that party's case. ${ }^{17}$ This jury instruction is commonly referred to as a "spoliation inference."

Although courts generally agree that a spoliation inference is appropriate only if the spoliating party has violated a duty to preserve evidence, ${ }^{19}$ courts have disagreed about two possible additional requirements for the inference. First, courts differ in their approaches to the spoliator's state of mind. ${ }^{20}$ Evidence can be spoliated along a continuum of culpability - it can be destroyed innocently, negligently, recklessly, intentionally, or in bad faith. ${ }^{21}$ Must the nonspoliating party establish the culpability of the spoliator before a spoliation inference is issued? If so, what is the minimum level of culpability that must be shown?

Second, courts differ about the need for the nonspoliating party to provide circumstantial proof that the spoliated evidence would have been unfavorable to the spoliating party. ${ }^{22}$ While some courts require the nonspoliating party to provide circumstantial evidence merely to establish the identity of the spoliated evidence, other courts

15. See Charles R. Nesson, Incentives to Spoliate Evidence in Civil Litigation: The Need for Vigorous Judicial Action, 13 CARDOZO L. REV. 793, 806 (1991) (describing the critical role judges play in fashioning spoliation remedies).

16. See infra notes 50-58 and accompanying text.

17. Another example of the spoliation inference jury instruction can be found in McLain v. Taco Bell Corp., 527 S.E.2d 712, 715 (N.C. Ct. App. 2000):

I instruct you that evidence has been presented in this case which tends to show that the Defendant ... either destroyed or failed to produce corporate records in its exclusive possession requested by the plaintiff in this case. If you determine this to be the case, then those [sic] would be a presumption or adverse inference against the Defendant ... that the evidence withheld would have injured the Defendants['] ... defense in this case.

18. The spoliation inference also is referred to in the literature as the "adverse inference." See, e.g., David A. Bell, Margaret M. Koesel \& Tracey L. Turnbull, Let's Level the Playing Field: A New Proposal for Analysis of Spoliation of Evidence Claims in Pending Litigation, 29 ARIZ. ST. L.J. 769, 790 (1997).

19. See infra Part I.A.

20. See infra Part II.A.

21. Although "spoliation" may be defined as the intentional destruction of evidence, see BLACK'S LAW DICTIONARY, supra note 14, at 1409, this Note adopts the broader definition of spoliation employed by courts. See infra Part II.A.

22. See infra Part II.B. 
require the nonspoliating party to provide circumstantial evidence of the contents of the spoliated evidence before the jury instruction will be issued. Must the nonspoliating party present circumstantial evidence regarding the spoliated evidence? If so, must the circumstantial evidence indicate that the spoliated evidence would have been adverse to the spoliating party?

This Note proposes a framework for understanding these two requirements. While other responses to spoliation attempt to punish the spoliating party or deter litigants from spoliating evidence, the spoliation inference is predominantly employed as a remedial tool to restore balance in the pending litigation. ${ }^{23}$ In light of the remedial role of the spoliation inference vis-à-vis other spoliation remedies, the culpability requirement and the circumstantial evidence requirement should work in concert to serve the same fundamental purpose-to ensure, through the introduction of secondary evidence, that the spoliation inference actually will advance the objective of restoring adversarial balance. In the Conclusion, this Note proposes a set of principles that are fairly drawn from this refined understanding of the relationship between the culpability and circumstantial evidence requirements.

\section{SPOLIATION OF EVIDENCE}

The prevalence of spoliation in civil litigation is alarming. In 1991, a study reported that fifty percent of all litigators consider spoliation to be a frequent or regular occurrence. ${ }^{24}$ Less than ten years later, the Tort and Insurance Practice Section of the American Bar Association published the first book devoted solely to the developing law of spoliation, ${ }^{25}$ in which the authors characterize spoliation as an "unfortunate reality of modern-day civil litigation." ${ }^{26}$ Other commentators have likewise noted that "deliberate obstructionism is com-

23. See infra note 68 and accompanying text.

24. Nesson, supra note 15, at 793.

25. Margaret M. Koesel, David A. Bell \& Tracey L. Turnbull, Spoliation of EVIDENCE: SANCTIONS AND REMEDIES FOR DESTRUCTION OF EVIDENCE IN CIVIL LITIGATION (2000). The proliferation of articles on spoliation of evidence may contribute to the "hype and trepidation" surrounding this concern. Jeffrey S. Kinsler \& Anne R. Keyes MacIver, Demystifying Spoliation of Evidence, 34 TORT \& INS. L.J. 761, 761 n.2 (1999).

26. KOESEL, Bell \& TURnBull, supra note 25 , at xi. 
monplace" 27 and that it is "difficult to exaggerate the pervasiveness of evasive practices." 28

In response to the rise of spoliation cases nationwide, courts are subjecting spoliation to intense scrutiny. ${ }^{29}$ One court has noted that the "[d]estruction or loss of potentially relevant evidence is a longstanding problem, but it has attracted increased attention in the past decade, ${ }^{, 30}$ and this attention has prompted rather rapid development of spoliation law. ${ }^{31}$ Although the judicial approaches to spoliation vary widely across jurisdictions, ${ }^{32}$ and although this variance poses particular problems because courts have failed to agree on choice-oflaw principles in the realm of spoliation, ${ }^{33}$ it is nevertheless reassuring to upstanding litigators that recent decisions indicate the "beginning of a nationwide anti-spoliation trend., ${ }^{34}$

\section{A. The Duty to Preserve Evidence}

Spoliation hinges upon the duty borne by each party to preserve potentially relevant evidence; as some scholars note, "the duty to preserve evidence is an absolute prerequisite for imposing sanctions on a

27. Edward J. Imwinkelried, A New Antidote for an Opponent's Pretrial Discovery Misconduct: Treating the Misconduct at Trial as an Admission by Conduct of the Weakness of the Opponent's Case, 1993 BYU L. REV. 793, 794.

28. Wayne D. Brazil, Civil Discovery: Lawyers' Views of Its Effectiveness, Its Principal Problems and Abuses, 1980 AM. B. Found. RES. J. 787, 829.

29. Bell, Koesel \& Turnbull, supra note 18, at 771.

30. Henderson v. Tyrrell, 910 P.2d 522, 531 (Wash. Ct. App. 1996).

31. MCCORMICK ON EVIDENCE $§ 265$, at 193-94 (John W. Strong ed., 4th ed. 1992) [hereinafter MCCORMICK] ("This area of the law appears to be in the process of rather rapid change, although the patterns of the new order are not yet entirely clear.").

32. See Bell, Koesel \& Turnbull, supra note 18, at 791 ("Thus far, judicial treatment of spoliation claims arising in the context of pending litigation has been inconsistent."); see also KOESEL, BELl \& TURNBUlL, supra note 25, at 75-201 (summarizing the developing law of spoliation in civil matters in state and federal courts).

33. KOESEL, BELl \& TURnBull, supra note 25 , at 2 :

The forum in which spoliation occurs can have a substantial impact on the resulting remedies available to the nonspoliating party, because courts disagree... about whose law applies.

Although state courts apply the forum law to spoliation claims, federal courts sitting in diversity disagree about whether spoliation that occurs during pending litigation is a substantive matter, to be governed by state law, or a procedural matter, subject to federal law.

17.

34. Sam LaManna, Courts Take a Harder Line on Spoliation, NAT'L L.J., July 26, 1993, at 
party for spoliation." ${ }^{35}$ This duty derives from three sources. First, a duty to preserve evidence may be imposed by statute, by regulation, or by the ethical duties of the profession. ${ }^{36}$ Second, the duty may attach if the party voluntarily assumes such a duty, as when a business implements a formal document retention policy. ${ }^{37}$ Third, and most importantly, the duty arises when litigation is filed, threatened, or reasonably foreseeable. ${ }^{38}$ Because the duty to preserve relevant evidence may arise before litigation is formally commenced, a party ${ }^{39}$ can

35. Laurie Kindel \& Kai Richter, Spoliation of Evidence: Will the New Millennium See a Further Expansion of Sanctions for the Improper Destruction of Evidence?, 27 WM. MITCHELL L. REV. 687, 689 (2000).

36. KOESEL, BELL \& TURNBUlL, supra note 25 , at 4,8 .

37. $I d$. at 9 .

38. Kindel \& Richter, supra note 35, at 689 (footnotes omitted) (quoting Kinsler \& MacIver, supra note 25 , at 764 ):

$[T]$ he duty [to preserve evidence] automatically arises when a party serves or is served with a judicial or administrative complaint. In such a situation, the party has actual knowledge that litigation has begun, and is therefore bound to preserve all discoverable evidence. However, this duty also arises where litigation is reasonably foreseeable, but has not yet officially commenced. There are many situations where there are pre-litigation communications between and among the parties that demonstrate that, at the time of the communications, the parties anticipated a lawsuit. The duty also arises when a party is on notice of a potential action because it has a history of lawsuits concerning a particular product or matter and could reasonably expect to be drawn into litigation concerning the same or similar matters. Thus, the duty to preserve evidence is triggered not only by the commencement of litigation, but also when a party is on notice that litigation is "likely to be commenced."

Kinsler \& MacIver, supra note 25, at 763 ("Absent actual notice, all forms of spoliation liability turn on foreseeability.").

39. Although the parties to litigation frequently perpetrate spoliation, spoliation also may be perpetrated by nonparties (such as a third-party insurer) or by witnesses (often a party's expert witness during the examination or investigation of physical evidence). See, e.g., Vodusek v. Bayliner Marine Corp., 71 F.3d 148, 157 (4th Cir. 1995) (determining that remedies for spoliation are available if the district court concludes that a party or her agent, in this case an expert witness, destroyed relevant evidence); Thompson v. Owensby, 704 N.E.2d 134, 137 (Ind. Ct. App. 1998) (concluding that an insurer's knowledge of a party's claim and the insurer's possession of key evidence created a relationship between the insurer and the party that weighed in favor of the insurer's duty to preserve the evidence). As with the parties to litigation, nonparties and witnesses must be subject to a duty to preserve relevant evidence before the destruction of such evidence constitutes spoliation. As a general rule, nonparties and witnesses are not subject to a duty to preserve relevant evidence. Koplin v. Rosel Well Perforators, Inc., 734 P.2d 1177, 1179 (Kan. 1987) ("[T]he general rule is that there is no duty to preserve possible evidence for another party to aid that other party in some future legal action against a third party."). This general rule does not apply, however, when the non-party or witness is bound by a special relationship with a party to the litigation, whether by agreement, contract, statute, or some other special circumstance. Id. 
spoliate evidence prior to the commencement of litigation, after litigation commences, or during the trial itself. ${ }^{40}$

The duty to preserve evidence extends to all evidence that might be "relevant" in reasonably foreseeable litigation. ${ }^{41}$ Relevancy must be interpreted with reference to the applicable evidentiary rules of each jurisdiction, and in most jurisdictions the concept of relevancy closely tracks its treatment in the Federal Rules of Evidence. Under the Federal Rules of Evidence, "relevant evidence" is "evidence having any tendency to make the existence of any fact that is of consequence to the determination of the action more probable or less probable than it would be without the evidence." ${ }^{42}$ Although the scope of relevant evidence must be viewed from the perspective of the party charged with the duty to preserve, ${ }^{43}$ the breadth of relevancy has prompted commentators to caution that "a party deciding whether to preserve particular items of evidence would be well advised to err on the side of caution." ${ }^{44}$

Courts have mitigated the early onset of the duty to preserve evidence (which attaches whenever litigation is reasonably foreseeable) and the expansive scope of this duty (which extends to all evidence with any tendency to make a material fact more or less probable) by limiting the duty by a standard of reasonableness. In the oftquoted language of the court in Hirsch v. General Motors Corp., ${ }^{45}$ "The scope of the duty to preserve evidence is not boundless. A "potential spoliator need do only what is reasonable under the circumstances." ${ }^{46}$ Courts may consider issues of safety, expense, and cum-

40. Kenneth R. Lang et al., Spoliation of Evidence: The Continuing Search for a Remedy and Implications for Aviation Accident Investigations, 60 J. AIR L. \& COM. 997, 1000 (1995).

41. Kedigh, supra note 14, at 598 ("Spoliation is the destruction, alteration or suppression of evidence relevant to a cause of action or potential cause of action.").

42. FED. R. EVID. 401.

43. KoESEL, Bell \& TURnBull, supra note 25, at 9 ("In addition to determining whether a duty exists to preserve evidence, a party also must decide what evidence should be preserved.... [T] he test is one of reasonableness, as seen from the perspective of the party charged with that duty.").

44. Id.

45. 628 A.2d 1108 (N.J. Super. Ct. Law Div. 1993).

46. Id. at 1122 (quoting County of Solano v. Delancy, 264 Cal. Rptr. 721, 731 (Cal. Ct. App. 1989)). 
bersomeness in determining whether the preservation of relevant evidence is reasonable. ${ }^{47}$

\section{B. Responding to Spoliation}

When evidence is spoliated, courts typically craft a remedy with three distinct objectives in mind: remediation, punishment, and deterrence. ${ }^{48}$ The remedial goal aims to restore the adversarial balance-to "level the playing field" spoliator in the pending litigation. The punishment objective reflects the judicial desire to sanction conduct that threatens the fair and equitable administration of justice. The third goal, deterrence, attempts to discourage future spoliation, and this goal is primarily advanced indirectly through the punitive sanctions employed to punish a spoliator. In pursuit of these objectives, courts may employ two different approaches to confront the evils of spoliation.

When a trial court determines that a party has spoliated evidence in a pending civil suit, the trial court may rely on collateral proceedings to address the acts of spoliation. These collateral proceedings can

47. Koesel, Bell \& TURnBull, supra note 25, at 9. In their eminently instructive book, Koesel, Bell, and Turnbull introduce Conderman v. Rochester Gas \& Electric Corp., 693 N.Y.S.2d 787 (N.Y. App. Div. 1999), as an example of a court considering the safety of preserving relevant evidence when deciding whether a party had violated the duty to preserve evidence. KOESEL, Bell \& TURNBUll, supra note 25, at 9-10. In Conderman, the plaintiffs were injured when they were hit by a falling utility pole as they drove through a town. 693 N.Y.S.2d at 788 . The utility company sent emergency crews to the site, and the crews removed the pole from the road by cutting the pole into four-foot sections. Id. The New York appellate court reversed the lower court's decision granting summary judgment to the plaintiffs because the utility company was responding to an emergency situation that affected public safety. Id. at 789. The court concluded that the utility company should not be expected to preserve the utility poles for possible pending litigation. Id.

48. See, e.g., Shaffer v. RWP Group, Inc., 169 F.R.D. 19, 25 (E.D.N.Y. 1996) (“An adverse inference charge serves the dual purposes of remediation and punishment."); Turner v. Hudson Transit Lines, Inc., 142 F.R.D. 68, 75 n.3 (S.D.N.Y. 1991) ("The adverse inference thus acts as a deterrent against even the negligent destruction of evidence.").

49. Lang et al., supra note 40, at 1001. 
include criminal prosecutions, ${ }^{50}$ independent tort actions, ${ }^{51}$ and professional disciplinary proceedings. ${ }^{52}$ Such proceedings would be initiated by a party other than the trial court, ${ }^{53}$ and the availability of these responses would be governed by statute, case precedent, and the ap-

50. Criminal liability is the most severe judicial response to spoliation, and it is employed rarely. See Kristin Adamski, Comment, A Funny Thing Happened on the Way to the Courtroom: Spoliation of Evidence in Illinois, 32 J. MARSHALL L. REV. 325, 346 (1999) ("[T]here are no cases where a party was criminally convicted for the spoliation of evidence in civil litigation."). Under federal law, spoliation of evidence could be prosecuted under several statutes, including 18 U.S.C. $§ 1503$ (2000), which prohibits the obstruction of justice, and 18 U.S.C. $§ 2071$ (2000), which criminalizes the destruction, mutilation, or concealment of any document filed in a federal court or public office. State laws also may provide the foundation for criminal liability, although such laws tend to vary dramatically across states. See Scott S. Katz \& Anne Marie Muscaro, Spoilage of Evidence-Crimes, Sanctions, Inferences, and Torts, 29 TORT \& INS. L.J. 51, 53 n.17 (1993) (cataloging state statutes that prohibit the destruction of evidence). Commentators often acknowledge two primary shortcomings of this response to spoliation: first, criminal prosecutions fail to satisfy the judicial objective of remediation because they do not reinstate adversarial balance in the primary civil suit, and second, criminal prosecutions do not provide sufficient deterrence because they are almost never feasible in light of the scarcity of prosecutorial resources. KOESEL, BELL \& TURNBULL, supra note 25, at 69-70.

51. Beginning with Smith v. Superior Court, 198 Cal. Rptr. 829 (Cal. Ct. App. 1984), overruled by Cedars-Sinai Med. Ctr. v. Superior Court, 954 P.2d 511 (Cal. 1998), several states have recognized a tort for spoliation of evidence. Although only five states had recognized the cause of action in 1997, that number had increased to twelve (and the District of Columbia) by 2000. Koesel, Bell \& TuRnBull, supra note 25, at 50 n.2; Bell, Koesel \& Turnbull, supra note 18, at 778 . The scope of the tort differs greatly across jurisdictions. Id. Although some commentators have acknowledged that the independent tort of spoliation of evidence acts as a meaningful deterrent and compensates the nonspoliating party, most jurisdictions have opted not to recognize the tort because, among other reasons, alternative remedies can respond adequately to the spoliation problem. Compare Steffen Nolte, The Spoliation Tort: An Approach to Underlying Principles, 26 ST. MARY's L.J. 351, 355-56 (1995) (contending that the spoliation tort promotes deterrence more effectively than traditional procedural remedies), with KOESEL, BELL \& TURNBULL, supra note 25, at 53 (observing that some courts have declined to recognize the tort because other remedies are available).

52. Spoliation may have significant professional ramifications for a spoliating party's counsel. When counsel is retained in anticipation of future litigation, one court observed, the obligation to preserve evidence "ran first to counsel, who had a duty to advise his client of the type of information potentially relevant to the lawsuit and of the necessity of preventing its destruction.” Turner v. Hudson Transit Lines, Inc., 142 F.R.D. 68, 73 (S.D.N.Y. 1991). According to Rule 3.4(a) of the American Bar Association's Model Rules of Professional Conduct, a lawyer shall not "unlawfully obstruct another party's access to evidence or unlawfully alter, destroy or conceal a document or other material having potential evidentiary value" and "shall not counsel or assist another person to do any such acts." MODEL RULES OF PROF'L CONDUCT R. 3.4(a) (2001). Although misconduct charges for breach of Rule 3.4 are infrequent, attorneys can be subjected to serious sanctions (including disbarment) and malpractice liability if they spoliate evidence. Kindel \& Richter, supra note 35, at 701.

53. In the case of criminal prosecutions, the initiating party would be the government; in the case of independent tort actions, it would be the nonspoliating party; in the case of disciplinary proceedings, it would be a professional organization, possibly at the behest of the nonspoliating party. 
propriate mechanisms for investigating allegations of professional misconduct.

In the alternative, a trial court may opt to rectify spoliation by imposing a sanction in the pending litigation, ${ }^{54}$ and the available sanctions vary considerably. The harshest sanction brings about the complete adverse disposition of a case in favor of the nonspoliating party through a dismissal of a plaintiff-spoliator's claim ${ }^{55}$ or a default judg-

54. A trial court derives its authority to sanction parties from the rules of civil procedure and the court's inherent authority. Under the Federal Rules of Civil Procedure (and many state rules of civil procedure), a trial court may sanction the spoliating party pursuant to the provisions of Rule 11 and Rule 26, though Rule 37 ("Failure to Make or Cooperate in Discovery; Sanctions") remains the most frequently employed basis for evidentiary sanctions. Kindel \& Richter, supra note 35, at 692:

Because spoliation of evidence clearly violates the spirit of discovery, a wide range of sanctions may be imposed under the Rules of Civil Procedure, including dismissal of the lawsuit, entry of a default judgment, exclusion of evidence and testimony, and assessing monetary penalties. Typically, Rule 37 provides the vehicle for imposing such sanctions.

The rules of civil procedure empower a trial court to sanction spoliation only when it occurs during the pendency of litigation, however; the rules do not vest courts with the authority to sanction spoliation that occurs before litigation commences. See Beil v. Lakewood Eng'g \& Mfg. Co., 15 F.3d 546, 552 (6th Cir. 1994):

This court's decision is in no way meant to condone pre-litigation destruction of evidence. The court simply recognizes that Rule 37 is a procedural rule, and like all procedural rules, it governs conduct during the pendency of a lawsuit. Rule 37 does not, nor does any procedural rule, apply to actions that occurred prior to the lawsuit.

Cited in Koesel, Bell \& TuRnBull, supra note 25, at 29.

If spoliation occurs before litigation commences, the trial court must rely on its inherent authority to sanction the spoliating party. For a discussion of the power of federal courts to sanction spoliation pursuant to their inherent authority, see generally Iain D. Johnston, Federal Courts' Authority to Impose Sanctions for Prelitigation or Pre-Order Spoliation of Evidence, 156 F.R.D. 313 (1994). Although a court's inherent authority should be exercised with great caution, Chambers v. NASCO, Inc., 501 U.S. 32, 43 (1991), it is virtually beyond dispute that "the inherent power to protect against destruction of evidence is necessary to ensure the proper administration of justice." KOESEL, BELL \& TURNBULL, supra note 25, at 30.

A court has wide latitude in its selection of sanctions pursuant to the applicable rules of civil procedure and its inherent authority. Sanctions imposed pursuant to Rule 37 of the Federal Rules of Civil Procedure are reviewed only for a clear abuse of discretion, e.g., Hazen v. Pasley, 768 F.2d 226, 229 (8th Cir. 1985), and the same is true of sanctions imposed under a court's inherent authority, e.g., Primus Auto. Fin. Servs., Inc. v. Batarse, 115 F.3d 644, 648 (9th Cir. 1997).

55. Some commentators refer to spoliation as an affirmative defense in the instances in which spoliation has prompted trial courts to dismiss plaintiffs' claims in products liability suits. See, e.g., Robert L. Tucker, The Flexible Doctrine of Spoliation of Evidence: Cause of Action, Defense, Evidentiary Presumption, and Discovery Sanction, 27 U. TOL. L. REV. 67, 74-77 (1995). 
ment rendered against a defendant-spoliator. ${ }^{56}$ If a dismissal or a default judgment would be unjustifiably harsh, a court may impose the ostensibly milder sanction of excluding secondary evidence or expert testimony offered by the spoliating party that relates to the spoliated evidence. ${ }^{57}$ Although the exclusion of evidence or expert testimony is less severe than outright dismissal or a default judgment, this sanction may have the same operative effect: after excluding secondary evidence or expert testimony, the trial court may be compelled to award summary judgment in favor of the nonspoliating party because the spoliating party may no longer be able to sustain its case. ${ }^{58}$ The final sanction available to the court is the spoliation inference, which is described in detail in the following Section.

\section{The Spoliation Inference}

The spoliation inference jury instruction empowers the members of the jury, as they see fit, to draw an adverse inference against the

56. This sanction is rarely employed because it dispossesses the spoliating party of the right to have the case adjudicated on its merits. KOESEL, BELL \& TURnBULL, supra note 25, at 45. Courts generally view the sanction of dismissal or default judgment as a last resort. E.g., Computer Assocs. Int'l, Inc. v. Am. Fundware, Inc., 133 F.R.D. 166, 169 (D. Colo. 1990) (noting that default judgments are reserved for egregious offenses against a party or the court). Consequently, they reserve the sanction of complete adverse disposition for those circumstances uniquely deserving of this severe remedy, which are often characterized by egregious bad faith or the lack of another suitable judicial response. KoESEL, BELL \& TURNBULL, supra note 25, at 45.

57. Tucker, supra note 55, at 76. In determining the propriety of excluding secondary evidence relating to the spoliated evidence, courts generally will consider the degree of prejudice caused by the spoliation, whether the prejudice can be cured, the practical importance of the secondary evidence, whether the spoliator was acting in bad faith, and the potential for abuse if the secondary evidence is admitted. Headley v. Chrysler Motor Corp., 141 F.R.D. 362, 365 (D. Mass. 1991). In determining the propriety of excluding expert testimony, courts may be persuaded that an expert should not be permitted to share firsthand knowledge of relevant evidence after that evidence has been destroyed by the expert or the party retaining that expert. Lang et al., supra note 40, at 1017 . When the trial court believes that the nonspoliating party is entitled to the benefit of the spoliation inference, see infra Part I.C, the exclusion of expert testimony may prove indispensable. If the nonspoliating party must rely on the benefit of the spoliation inference while the spoliating party gains the benefit of an expert witness's testimony (which is uncontroverted because the evidence has been spoliated), the spoliation inference may cease to offer any relief to the nonspoliating party.

58. Lang et al., supra note 40, at 1015; see also Simons v. Mercedes-Benz of N. Am., Inc., No. 95-2705, 1996 U.S. Dist. LEXIS 2695, at*13 (E.D. Pa. Mar. 7, 1996) ("[I]n such cases, the judgment itself is not the sanction; rather, the exclusion of the evidence is the sanction. 'Judgment only follows because the party cannot otherwise prove its case."') (quoting Donohue v. Am. Isuzu Motors, Inc., 155 F.R.D. 515, 520 (M.D. Pa. 1994)); KoESEL, BELL \& TURNBUlL, supra note 25, at 42 (quoting the same language from the Simons decision). 
spoliating party. ${ }^{59}$ In its simplest form, the spoliation inference may resemble the following instruction:

When evidence is within the control of a party whose natural interests it would be to produce that evidence, and that party destroys the evidence without adequate cause, it may be inferred that such evidence would be unfavorable to that party. ${ }^{60}$

Although the spoliation inference is only one option among the court's arsenal of potential responses to spoliation, the spoliation inference is prominently employed because its use comports with the judicial commitment to "select the least onerous sanction corresponding to the willfulness of the destructive act and the prejudice suffered by the victim." ${ }^{61}$ Unlike a collateral proceeding (such as an independent tort action based on intentional or negligent spoliation), the use of the spoliation inference avoids the costs of collateral litigation. $^{62}$ And in contrast to the extreme remedies of dismissal or default judgment, the spoliation inference may be the most appropriate and proportional judicial response. ${ }^{63}$

59. The spoliation inference also enjoys a noble pedigree dating back to Armory v. Delamirie, 93 Eng. Rep. 664 (K.B. 1722), the famous chimney-sweep's jewel case. For a summary of the case, see Jesse DuKeminier \& JAmes E. Krier, Property 104 (3d ed. 1993). In $A r-$ mory, a chimney-sweep's boy found a jewel and took the jewel to a goldsmith's shop. Id. The goldsmith's apprentice, under pretense of weighing the jewel, removed the precious stones and informed the goldsmith that the jewel was worth three half-pence. Id. When the chimneysweeper's boy refused to accept three half-pence for the stones, the apprentice returned the socket to the boy without the precious stones. $I d$. In an action in trover, several individuals in the jewel trade testified to the maximum value of a jewel that could fit in the socket. Id. The chief justice instructed that unless the defendant produced the jewel and showed that it was not "of the finest water, the jury should presume the strongest against him, and make the value of the best jewels the measure of their damages, which they accordingly did." Id. In issuing this adverse inference instruction to the jury, the chief justice in Armory also announced the legal maxim that would forever be associated with the spoliation inference: "contra spoliatorem omnia praesumuntur"- "All things are presumed against the spoliator." KOESEL, BELL \& TURNBULL, supra note 25 , at xiii.

60. Henderson v. Tyrrell, 910 P.2d 522, 534 (Wash. Ct. App. 1996).

61. James Gorelick, Destruction of EVIDENCE § 3.16, at 117 (1989); see also Gates Rubber Co. v. Bando Chem. Indus., Ltd., 167 F.R.D. 90, 106 (D. Colo. 1996) (concluding that courts should employ the "least onerous sanction" to remedy spoliation); Patton v. Newmar Corp., 520 N.W.2d 4, 8 (Minn. Ct. App. 1994) (concluding that a court has a "duty to impose the least restrictive sanction available under the circumstances" in a spoliation case), rev'd on other grounds, 538 N.W.2d 116 (Minn. 1995).

62. Koesel, Bell \& TURnbull, supra note 25, at 40.

63. To draw on a popular analogy, the spoliation inference may be the judiciary's "cardboard sword" properly employed to slay a mouse:

In general, a trial court confronted by sanctionable behavior should consider the purpose to be achieved by a given sanction and then craft a sanction adequate to 
Despite the value of the inference as a less severe response to spoliation, some courts and commentators criticize the spoliation inference because it fails to advance the objectives of punishment and deterrence. Standing alone, the spoliation inference is insufficient to punish a spoliator in pending litigation or deter a potential spoliator from destroying or altering relevant evidence. The inference fails as a punitive response because, even in its strongest application, it attempts only to level the playing field. ${ }^{64}$ It is equally true that the inference fails as a deterrent because the inference is permissive rather

serve that purpose. While we eschew the imposition of rigid guidelines for the trial courts in this circumstance-specific area of the law, the judge should take pains neither to use an elephant gun to slay a mouse nor to wield a cardboard sword if a dragon looms.

Anderson v. Beatrice Foods Co., 900 F.2d 388, 395 (1st Cir. 1990) (citations omitted).

64. Koesel, Bell \& TuRnbull, supra note 25, at 41. The spoliation inference's scienter requirement plays a particularly important role in evaluating the punitive effect of the inference. When a party destroys evidence intentionally or in bad faith, a fair presumption arises that the spoliated evidence may have been unfavorable to that party. In these cases, the spoliation inference fails to serve a punitive purpose because the inference attempts only to level the playing field. When evidence is spoliated in bad faith, it is unlikely that the spoliating party will perceive the inference as a punishment at all; a party that spoliates evidence in bad faith would almost always prefer a permissive spoliation inference to the introduction of the evidence. On this basis, alternative responses to spoliation are best suited to address intentional or bad faith spoliation. On the other hand, as the culpability of the spoliator decreases from intentionality to recklessness, negligence, or innocence, the punitive role of the spoliation inference is enhanced. In these circumstances, the spoliating party (which has acted recklessly, negligently, or innocently) might very well perceive the spoliation inference as a punishment because the inference may prove far more damning than the spoliated evidence. This Note contends that this punitive aspect of the spoliation inference is undesirable for two reasons. First, it creates a disturbing dynamic wherein the severity of punishment increases as the culpability of the spoliator decreases. Second, some commentators contend that the spoliation inference permits the jury to consider evidence that has not been submitted, a notion "inimical to the U.S. judicial system." Jerrold Abeles \& Robert J. Tyson, Spoil Sport, L.A. LAwYer, May 1999, at 41, 46, quoted in Koesel, BELL \& TURNBULL, supra note 25 , at 41 . It is inappropriate to permit the jury to consider evidence that has not been submitted as a means to punish a party-particularly an innocent party - when evidence has been destroyed. 
than mandatory ${ }^{65}$ - the jury decides the impact of the inference ${ }^{66}$ and it may reject the inference outright. ${ }^{67}$

Although the spoliation inference serves the remediation objective almost to the exclusion of deterrence or punishment, ${ }^{68}$ the concern that the inference does not punish wrongdoers is largely without merit. The spoliation inference may be relatively toothless compared with its counterparts, but a court will not be compelled to employ the spoliation inference in cases in which a spoliator's conduct should be punished more severely. ${ }^{69}$ The relative weakness of the spoliation inference as a means of punishment does not diminish its value in cases in which a court needs only to employ a milder sanction to "level the playing field."

A similar critique can be made of the inference's failure to deter spoliation. The deterrent effect of the spoliation inference should not be evaluated in isolation. Instead, the deterrent nature of the entire spoliation regime (which, depending on the jurisdiction, may include civil or criminal liability, professional sanctions, discovery sanctions, and/or the threat of dismissal or default judgment) is the appropriate

65. Blinzler v. Marriott Int'l, Inc., 81 F.3d 1148, 1159 (1st Cir. 1996). At best, the spoliation inference may deter parties from allowing evidence to be spoliated through the parties' negligence or recklessness. The inference, standing alone, is powerless to deter bad faith spoliation (because the inference will never be more damning than the evidence), and it is likewise powerless to deter innocent spoliation (because the party was not culpable). In rare circumstances, therefore, the potential availability of the spoliation inference may persuade a party to avoid any negligent or reckless conduct that may result in the destruction of relevant evidence. This Note contends that this deterrent effect is misunderstood. The spoliation inference is permissive, and it is unclear whether a party's negligence or recklessness would be affected by the potential availability of a permissive inference. And if a potential spoliator contemplates the availability of the spoliation inference when it determines whether it should act negligently or recklessly, it appears equally clear that the potential spoliator will consider all of the other possible responses to spoliation. Because other responses to spoliation are harsher than the inference, the potential spoliator's a priori consideration of the inference should never singlehandedly deter a spoliator.

66. KOESEL, Bell \& TURNBULL, supra note 25, at 41.

67. Blinzler, 81 F.3d at 1159 .

68. Although some courts have suggested that the spoliation inference serves to punish wrongdoers, see, e.g., Shaffer v. RWP Group, Inc., 169 F.R.D. 19, 25 (E.D.N.Y. 1996) (noting that such an inference serves the dual purposes of remediation and punishment), this proposition seems defensible only if juries entertain an inference against the spoliator that is far more detrimental to the spoliator's case than the destroyed evidence would have been. Evaluating the frequency of this circumstance is difficult because the impact of the inference is determined entirely by the jury. See supra note 66 and accompanying text.

69. To return to the analogy presented earlier, see supra note 63 , a court will not be compelled to use the spoliation inference's cardboard sword when a judicial elephant gun would be appropriate. 
unit for consideration because a potential spoliator will not know a priori which sanction the court will employ. Viewed as one response among many that can be employed to thwart a spoliator, the spoliation inference occupies a critical position in the judge's arsenal and may often prove to be the "least onerous sanction" available to rectify the destruction of potentially relevant evidence. Properly construed, the spoliation inference is a valuable and fundamentally remedial response to spoliation.

\section{TWO UNRESOLVED REQUIREMENTS: CULPABILITY AND CIRCUMSTANTIAL EVIDENCE}

\section{A. The Culpability Requirement}

Assume the following scenario. ${ }^{70}$ Amidst a devastating economic downturn marked by declining revenues, John Doe, the supervisor of Acme Widget Works, Inc., was informed by senior management that ten employees would be terminated pursuant to an involuntary reduction-in-force (RIF). Doe received a "supervisor's package" that described the appropriate procedures for identifying the ten employees to be terminated pursuant to the RIF. Doe was instructed to define skill sets, identify the number of employees required at each skill level, review the qualifications of each employee, select the most qualified employees, and identify surplus employees. Doe distributed this information to his three assistant supervisors, and over the following week he convened a series of meetings with his assistants to identify the ten employees to be terminated.

Two weeks later, Doe met with David Smith to inform him that he had been terminated under the RIF. Smith, a black male, alleged that his termination was motivated by race in violation of Title VII of the Civil Rights Act of $1964,{ }^{71}$ and he filed suit against Acme Widget Works. Smith contended that Doe and Doe's assistant supervisors deviated materially from the official instructions embodied in the supervisor's package and created their own system for identifying surplus employees. Pursuant to the rules of discovery, Smith sought access to the charts, notes, and other documents that recorded the

70. This scenario is loosely modeled on the underlying facts of Scott v. IBM Corp., 196 F.R.D. 233 (D.N.J. 2000).

71. 42 U.S.C. § 2000e-2(a)(1) (1994) (declaring that it shall be an unlawful employment practice for an employer to "discharge any individual . . . because of such individual's race, color, religion, sex, or national origin"). 
decisionmaking process employed in Doe's meetings with his assistant supervisors. At a minimum, these charts specified the standards employed by Doe and the rank order of the bottom fifteen "surplus" employees.

Now consider five explanations for the destruction of the charts, notes, and documents:

- Doe carefully collected the notes, charts, and documents from the meetings and placed them in a secure file in his office. Three days after the meetings concluded, however, Acme Widget Works was attacked by an arsonist, and all of the files in Doe's office were destroyed in the fire.

- Doe carefully collected the notes, charts, and documents from the meetings and placed them in a file in his office. Two days later, he decided to review the file during his lunch break at a local diner. When he arrived at the diner, however, he encountered an old friend, they dined together, and Doe inadvertently left the file on the table when he departed.

- Doe collected the notes, charts, and documents and placed them in a file in the corporate fileroom. Three days later, Doe asked a fileroom worker to organize the RIF file. Doe was aware that the same fileroom worker had discarded essential documents two months ago when instructed to "organize a sales file." The fileroom worker discarded the notes, charts, and documents.

- Following the meeting, Doe commented that the RIF meetings had generated a daunting amount of paperwork. Because Doe and his assistant supervisors were moving to another office, he feared that the massive paperwork would prove overly burdensome during the move. He collected all of the notes, charts, and documents and destroyed them.

- Following the meeting, Doe acknowledged that the RIF might prompt disgruntled surplus employees to file "frivolous" discrimination claims. He directed his assistant supervisors to submit all notes, charts, and documents from the RIF meetings to him to ensure that "the details of our decision will never see the light of day."

In these five scenarios, relevant evidence has been destroyed after Acme Widget Works (and John Doe) should have known that liti- 
gation was reasonably foreseeable. But these scenarios illustrate that a spoliator can act with significantly different levels of culpability, ranging from innocence to bad faith. Should a spoliation inference be available in all of these circumstances? And if not, where should the line be drawn?

Courts have differed widely in their approach to the scienter requirement for the spoliation inference. ${ }^{72}$ In some jurisdictions, the spoliation inference is available only if the evidence is destroyed in bad faith. ${ }^{73}$ Some courts have relaxed the culpability requirement slightly, however, concluding that the spoliation inference should be available even if the spoliator has intentionally destroyed the evidence without bad faith. ${ }^{74}$ Several courts have dispensed with the intent requirement altogether, permitting a spoliation inference instruction if the spoliator's conduct was reckless or grossly negligent. ${ }^{75}$ Lastly, some jurisdictions have relaxed the culpability requirement even more, and these courts may issue a spoliation inference instruction even if the spoliator's conduct was merely negligent. ${ }^{76}$

In stark contrast, commentators propose a strict liability approach to the spoliation inference. In an important article published in $1997,{ }^{77}$ David Bell, Margaret Koesel, and Tracey Turnbull ${ }^{78}$ propose

72. Kedigh, supra note 14 , at 598-99.

73. E.g., Brown \& Williamson Tobacco Corp. v. Jacobson, 827 F.2d 1119, 1134-35 (7th Cir. 1987); Wright ex rel. Wright v. Illinois Cent. R.R. Co., 868 F. Supp. 183, 188 (S.D. Miss. 1994); Scout v. City of Gordon, 849 F. Supp. 687, 691 (D. Neb. 1994). When the spoliation inference is confined to circumstances evincing the spoliator's bad faith, courts often conclude that "the inference presupposes that consciousness of wrongdoing motivated the spoliation, and that giving the instruction only makes sense if there was an intent to spoliate." KoESEL, BeLL \& TURNBULL, supra note 25, at 37.

74. E.g., Brewer v. Quaker State Oil Ref. Corp., 72 F.3d 326, 334 (3d Cir. 1995); Beers v. Bayliner Marine Corp., 675 A.2d 829, 832-33 (Conn. 1996); Collins v. Throckmorton, 425 A.2d 146, 150 (Del. 1980).

75. E.g., Reilly v. Natwest Mkts. Group Inc., 181 F.3d 253, 267-68 (2d Cir. 1999); Battocchi v. Wash. Hosp. Ctr., 581 A.2d 759, 767 (D.C. 1990).

76. E.g., Glover v. BIC Corp., 6 F.3d 1318, 1329 (9th Cir. 1993); Nation-Wide Check Corp. v. Forest Hills Distribs., Inc., 692 F.2d 214, 219 (1st Cir. 1982); Baliotis v. McNeil, 870 F. Supp. 1285, 1291-92 (M.D. Pa. 1994); Turner v. Hudson Transit Lines, Inc., 142 F.R.D. 68, 72 (S.D.N.Y. 1991).

77. Bell, Koesel \& Turnbull, supra note 18 .

78. Bell, Koesel, and Turnbull are private practice commercial litigation attorneys at the law firm of Porter, Wright, Morris \& Arthur. Id. at 769. Their proposal merits serious consideration in light of their recent book on spoliation published by the American Bar Association's Tort and Insurance Practice Section. See supra note 25 and accompanying text. 
that all spoliation sanctions-including the spoliation inference ${ }^{79}-$ should be issued without regard to the spoliator's culpability. ${ }^{80}$ If the alleged victim of spoliation can make a threshold showing that a spoliation remedy is necessary, ${ }^{81}$ they argue, the court should determine the proper remedy for spoliation without regard to the spoliator's state of mind. ${ }^{82}$

\section{B. The Circumstantial Evidence Requirement}

For centuries, courts disfavored the view that the spoliation inference, standing alone, operated as sufficient evidence of the contents of the spoliated evidence. ${ }^{83}$ John Henry Wigmore noted that

79. The authors conclude,

In relatively rare instances, the spoliated evidence will prejudice a party so severely that the only just result, harsh though it may be, is dismissal or default judgment. In many other cases, the exclusion of evidence, an adverse inference, or another remedy may be sufficient to remedy any prejudice. In still other cases, the spoliator will be able to show that the missing evidence is cumulative or trivial, in which case no prejudice will have occurred and no remedy will be necessary. The trial court is well placed to make these judgment calls.

Bell, Koesel \& Turnbull, supra note 18, at 802 (emphasis added). This excerpt clearly indicates that the authors would include a spoliation inference in their strict liability paradigm.

80. This framework is based in large part on three observations about the current state of spoliation jurisprudence. Initially, they note that courts employ a variety of tests to analyze spoliation when the issue arises in pending litigation. $I d$. at 799. Second, they observe that courts tend to focus on two considerations in fashioning a spoliation remedy: the spoliator's state of mind and the prejudice to the nonspoliating party. Id. Lastly, they note that courts often blur these two considerations, combining them into a single analysis. Id.

81. First, the nonspoliating party must show that the alleged spoliator was subject to a duty to preserve relevant or potentially relevant evidence. $I d$. at 799 . For further discussion of the duty to preserve relevant evidence, see supra Part I.A. Second, the nonspoliating party must make a showing that the alleged spoliator failed to preserve such evidence. Bell, Koesel \& Turnbull, supra note 18 , at 800 . Third, the nonspoliating party must show that it has suffered prejudice as a result of the spoliation. Id. The alleged spoliator is entitled to the opportunity to rebut this showing through the introduction of evidence tending to disprove one of the three threshold requirements. $I$.

82. Id. at 800 ("State of mind is not a consideration at this juncture."). Moreover, the authors assert without qualification that "[t]his analysis should not take into account the state of mind of the spoliator." Id. at 799. They justify this approach on three grounds: it ensures fairness by placing the adverse consequences of the loss of evidence on the party responsible for its destruction, it promotes the institutional interests of the adversarial system by promoting the search for truth, and it creates greater incentives for parties to preserve relevant evidence. Id. at 800-03.

83. See Hanson v. Eustace, 43 U.S. (2 How.) 653, 708 (1844) ("The refusal to produce books, under a notice, lays the foundation for the introduction of secondary evidence. It affords neither presumptive nor prima facie evidence of the fact sought to be proved by them."). It should be noted, however, that a distinction may be drawn between the failure to produce evidence-which may not provide prima facie evidence of the fact sought to be proven-and the 
"the real field for controversy remains ... whether the inference alone will suffice as evidence of the contents of the document in question." ${ }^{\prime 4}$ Although courts have departed considerably from the unqualified conviction that the spoliation inference is insufficient, absent extrinsic evidence, to serve as evidence of the contents of the spoliated evidence, judicial treatment of the circumstantial evidence requirement for the spoliation inference remains muddled.

Some courts remain reluctant to issue the inference instruction unless the nonspoliating party offers extrinsic evidence that the contents of the spoliated evidence were unfavorable to the spoliator. The rationale for this heightened circumstantial evidence requirement is most clearly articulated in Turner v. Hudson Transit Lines, Inc. ${ }^{85}$ In Turner, the plaintiff sued the operator of a bus after the bus was involved in a collision on the New Jersey turnpike. ${ }^{86}$ The plaintiff, a passenger on the bus, alleged that the bus's brakes were not in good order, and the plaintiff sought a spoliation inference because the bus's maintenance records had been destroyed. ${ }^{87}$ After the court determined that the bus operator's reckless conduct caused the loss of the bus's maintenance records ${ }^{88}$ the court focused its attention upon the controversial and often misunderstood circumstantial evidence requirement.

The court initially observed that "there must be some showing that there is in fact a nexus between the proposed inference and the information contained in the lost evidence." the court observed, would require only that the nonspoliating party establish the identity of the spoliated evidence. ${ }^{90}$ The Turner court,

destruction of evidence-which may provide presumptive evidence of the fact sought to be proven.

84. 2 JOHN HENRY WigmORE, Wigmore ON EVIDENCE § 291, at 227 (Chadbourn rev. ed. 1979). One commentator, answering in the negative, noted in 1806 that " "[w]hat is said . . respecting leaving the refusal [to produce relevant evidence] as a presumption to the jury should be received with considerable qualification; for it cannot be admitted that such a presumption should stand instead of all other evidence and supply the total deficiency of proof." Id. (quoting 2 W.D. EVANS, NOTES TO POTHIER 145 (1806)).

85. 142 F.R.D. 68 (S.D.N.Y. 1991).

86. Id. at 70 .

87. Id. at 70-71.

88. Id. at 76 .

89. Id.

90. Id. 
however, acknowledged that

in fact courts have generally required some greater showing of the content of the destroyed evidence before drawing an adverse inference.... [S] ome extrinsic evidence of the content of the evidence is necessary for the trier of fact to be able to determine in what respect and to what extent it would have been detrimental. This corroboration requirement is even more necessary where the destruction was merely negligent, since in those cases it cannot be inferred from the conduct of the spoliator that the evidence would even have been harmful to him. ${ }^{91}$

The court ultimately concluded that the spoliation inference is not warranted when there is no extrinsic evidence indicating that the spoliated evidence would have been unfavorable to the spoliating party. ${ }^{92}$

While some courts, like the Turner court, have required the presentation of extrinsic evidence that the contents of the spoliated evidence would have been adverse to the spoliator, ${ }^{93}$ several courts have declined to impose such a demand. These courts most often rely on the guidance of Professor John Henry Wigmore, who wrote,

The failure or refusal to produce a relevant document, or the destruction of it, is evidence from which alone its contents may be inferred to be unfavorable to the possessor, provided the opponent, when the identity of the document is disputed, first introduces some evidence tending to show that the document actually destroyed or withheld is the one as to whose contents it is desired to draw an inference. In applying this rule, care should be taken not to require anything like specific details of contents, but merely such evidence as goes to general marks of identity. ${ }^{94}$

This less demanding circumstantial evidence requirement-which requires that the nonspoliating party merely establish the identity of the spoliated evidence-may be referred to as "Wigmore's Rule."

\footnotetext{
91. Id. at 77 .

92. Id.

93. See Nation-Wide Check Corp. v. Forest Hill Distribs., Inc., 692 F.2d 214, 218-19 (1st Cir. 1982) (requiring that extrinsic evidence be relevant and probative to show that the spoliated evidence was adverse, but recognizing that the extrinsic evidence need not be independently sufficient to warrant such a conclusion); Stanojev v. Ebasco Servs., Inc., 643 F.2d 914, 923-24 (2d Cir. 1981) (finding that the failure to produce charts containing performance evaluations could not support an inference that an employee was discharged due to age discrimination).

94. WIGMORE, supra note $84, \S 291$, at 228 (emphasis added and emphasis omitted).
} 
Wigmore's Rule contemplates the destruction of a particular document known by both parties potentially to contain relevant evidence in the case. ${ }^{95}$ In Kronisch $v$. United States,${ }^{96}$ however, the United States Court of Appeals for the Second Circuit extended the scope of Wigmore's Rule. ${ }^{97}$ The plaintiff in Kronisch contended that he was unwittingly drugged with LSD in a Paris café as part of a confidential CIA research program. ${ }^{98}$ After the CIA destroyed all of its files related to the MKULTRA program, a study of the effects of chemical and biological agents on human behavior, the plaintiff argued that the spoliated files would have contained evidence that he was one of the subjects of the program. ${ }^{99}$ Because the entire file had been spoliated by the CIA, the plaintiff was unable to identify a particular document of crucial importance. ${ }^{100}$ In this "more complex" situation, however, the Kronisch court still opined that the basic principle underlying Wigmore's Rule was applicable. ${ }^{101}$ The court concluded,

Just how much evidence is enough to support an inference about the content of destroyed evidence cannot be precisely defined, and will necessarily vary from case to case, but we remain mindful of Wigmore's admonition that "care should be taken" not to require too specific a level of proof. Indeed, holding the prejudiced party to too strict a standard of proof regarding the likely contents of the destroyed evidence would subvert the prophylactic and punitive purposes of the adverse inference, and would allow parties who have intentionally destroyed evidence to profit from that destruction. ${ }^{102}$

The Kronisch court's approach to the circumstantial evidence requirement deviates significantly from the approach adopted by the Turner court. While the Turner court departed from Wigmore's Rule and held that extrinsic evidence of the contents of spoliated evidence is necessary, the Kronisch court adhered to-and even extendedWigmore's admonition that courts should not require evidence tending to show that spoliated evidence would have been adverse to

\footnotetext{
95. Id.

96. 150 F.3d 112 (2d Cir. 1998).

97. See id. at 128 (noting that "there can be no doubt that the same basic principle proposed by Wigmore still applies" when a party loses the opportunity to identify a document likely to contain important evidence because the files containing that particular document are destroyed).

98. Id. at 116 .

99. Id. at 118,129

100. Id.

101. Id.

102. Id. (citations omitted).
} 
to show that spoliated evidence would have been adverse to the spoliator.

\section{RECASTING THE CULPABILITY AND CIRCUMSTANTIAL EVIDENCE REQUIREMENTS}

Must the nonspoliating party establish the culpability of the spoliator before a spoliation inference is issued, and if so, what is the minimum level of culpability that must be shown? Must the nonspoliating party present circumstantial evidence regarding the spoliated evidence, and if so, must the circumstantial evidence indicate that the spoliated evidence would have been adverse to the spoliating party? Although several courts and commentators have addressed these important questions, a uniform national approach has not emerged. This Note contends that a uniform approach has not emerged because courts and commentators have failed to consider a third, more fundamental, question: how should the culpability and circumstantial evidence requirements work together to ensure that the spoliation inference properly serves its remedial purpose?

\section{A. Linking Culpability and Circumstantial Evidence}

A proper analysis of this question necessarily begins with Wigmore's Rule. The rule requires the nonspoliating party to introduce extrinsic evidence tending to show that the destroyed document was the document from which the desired inference would be drawn, but does not require the nonspoliating party to offer extrinsic evidence that the contents of the destroyed document were unfavorable to the spoliator. ${ }^{103}$ Thus, the rule proposes a departure from the "current of authority" that refuses to treat the spoliation inference as sufficient evidence of the contents of the destroyed evidence. ${ }^{104}$

Sadly, courts have failed to fully appreciate that this influential rule applies under the presumption that the spoliating party has engaged in the intentional destruction of evidence. Wigmore prefaces the articulation of his rule with the following observations:

[A]fter all, why is any additional evidence required as a matter of law? All that is asked is that the jury be allowed to make the infer-

103. See supra note 94 and accompanying text.

104. See WIGMORE, supra note $84, \S 291$, at 227 ("The truth is that there is no reason why the utmost inference logically possible should not be allowable, namely, that the contents of the document ... are what he alleges them to be."). 
ence if they are in truth convinced to that effect. What hardship or unfairness is involved to the possessor of the document? He has deliberately failed to show, by production, that which it was in his power to show, and he has by hypothesis given no other fact in explanation than the apparent one, namely, that he is afraid to submit the document to the tribunal's inspection. If there were any risk of the inference being too strong, would he not immediately make production? And does not his failure to do so indicate that the production would, in his belief, be more damaging to him than any inferences which the tribunal may make for lack of the document itself $^{105}$

The failure of courts to appreciate that Wigmore's Rule is presented in the context of intentional destruction belies a more significant shortcoming of spoliation jurisprudence: courts and commentators have failed to appreciate the relationship between culpability and the circumstantial evidence requirement.

Wigmore's approach to the spoliation inference implicitly recognizes a principle of utmost importance. The rule is premised on the rationale that extrinsic evidence of the contents should not be required because, by supposition, the evidence has been deliberately destroyed or withheld. The tacit assumption underlying Wigmore's approach, therefore, is that the circumstantial evidence requirement must bear some relation to the culpability requirement (and vice versa). Although this observation proves helpful in identifying a link between the culpability and circumstantial evidence inquiries, it leaves yet another question unanswered: why are these two apparently distinct requirements intertwined?

The spoliation inference primarily serves the purpose of remediation-it attempts to restore the adversarial balance that was disrupted when the spoliating party innocently, negligently, recklessly, or intentionally (with or without bad faith) permitted relevant evidence to be destroyed. ${ }^{106}$ But the destruction of evidence, standing alone, may not provide sufficient assurances that the inference will restore this balance. For instance, if evidence is destroyed innocently, there are no extrinsic indications that the evidence was adverse to the "spoliating" party and, as a result, the spoliation inference may work a substantial injustice. If the primary objective of the spoliation inference is the restoration of adversarial balance, the culpability and cir-

105. Id. (emphasis added).

106. See supra note 68 and accompanying text. 
cumstantial evidence requirements should be applied in a manner that aids courts in assuring that the spoliation inference is an equitable remedy.

In light of the remedial objective of the spoliation inference, it becomes apparent that the culpability requirement and the circumstantial evidence requirement serve the same fundamental purpose: to ensure that the spoliation inference is more likely to restore than disrupt the adversarial balance in pending litigation. The basic intuition behind the spoliation inference is the "common sense observation that a party who has notice that [evidence] is relevant to litigation and who proceeds to destroy [it] is more likely to have been threatened by [that evidence] than is a party in the same position who does not destroy the [evidence]." ${ }^{107}$ This common sense observation does not hold true, however, when the spoliator is innocent, and it likewise may not hold true when the spoliator is guilty of merely negligent or reckless conduct. As the culpability of the spoliating party increases (from innocence to bad faith conduct), the intuitive appeal of the "common sense" assumption underlying the inference increases. In contrast to collateral proceedings (such as a cause of action in tort), however, the culpability of the spoliator is not a central issue in assessing punishment or in gauging the need for deterrence. Instead, the spoliator's state of mind serves as a proxy for the contents of the evidence when the culpability of the spoliator is sufficiently high.

Similarly, when the nonspoliating party offers extrinsic evidence that the contents of the spoliated evidence are unfavorable to the spoliating party, it appears more likely that the spoliation inference is warranted. The application of the spoliation inference would be fairly effortless if extrinsic evidence of the contents of destroyed evidence were always available. Such evidence, even when the evidence is purely circumstantial, increases the court's confidence that an adverse inference instruction will not be unjust (i.e., it will restore adversarial balance and level the playing field). But the spoliation inference itself is a concession to the fact that such circumstantial evidence will not always (and may rarely) be available. Although the availability of such evidence reinforces the conviction that the spoliation inference is a fair remedy, the circumstantial evidence requirement must work

107. Koesel, Bell \& Turnbull, supra note 25, at 36 (quoting Nation-Wide Check Corp. v. Forest Hills Distribs., Inc., 692 F.2d 214, 218 (1st Cir. 1982)). 
in concert with other considerations, such as culpability, to establish the equity of a spoliation inference.

Bearing in mind the connection between the culpability requirement and the circumstantial evidence requirement, this Note proposes a framework to guide a court's preliminary consideration of a spoliation inference, as presented in Table 1:

\section{TABLE 1: A CULPABILITY/CIRCUMSTANTIAL EVIDENCE FRAMEWORK FOR THE SPOLIATION INFERENCE}

\begin{tabular}{|l|l|l|l|l|l|}
\hline Level of Culpability & Innocent & Negligent & Reckless & Intentional & $\begin{array}{l}\text { Bad } \\
\text { Faith }\end{array}$ \\
\hline $\begin{array}{l}\text { Circumstantial Evidence } \\
\text { Establishing the Contents } \\
\text { of the Spoliated } \\
\text { Evidence Required? }\end{array}$ & Yes & Yes & Yes & No & No \\
\hline $\begin{array}{l}\text { Circumstantial Evidence } \\
\text { Establishing the Identity } \\
\text { of the Spoliated } \\
\text { Evidence Required? }\end{array}$ & Yes & Yes & Yes & Yes & Yes \\
\hline
\end{tabular}

\section{B. Four Guiding Principles}

1. Circumstantial Evidence of Identity Is Always Required. In all circumstances, the nonspoliating party must provide adequate extrinsic proof that the spoliated evidence is, in fact, the evidence from which the nonspoliating party hopes to draw an inference. This proposition has not been challenged by courts or commentators. The nonspoliating party should be required to offer general marks of identity to meet this burden in accordance with Wigmore's Rule.

2. A Traditional Strict Liability Approach Is Inappropriate. The availability of the inference should not be determined without regard to the spoliator's state of mind. In certain circumstances, the spoliator's state of mind can eliminate the need for an independent requirement of extrinsic proof of the contents of the spoliated evidence. This aspect of the framework, which suggests that proof of bad faith 
or intentional destruction need not be supplemented by proof of the contents of the spoliated evidence, does not disturb the foundation of Wigmore's Rule.

3. Bad Faith Is Sufficient but Not Necessary. The framework proposed in this Note rejects the governing law in many jurisdictions that bad faith (or, in some jurisdictions, intent) is a requirement for the spoliation inference. In conformity with Wigmore's Rule, the framework recharacterizes bad faith and intent as sufficient but not necessary to activate the spoliation inference. Because the spoliation inference is a fundamentally remedial response, this framework does not foreclose the availability of the inference to rectify innocent, negligent, or reckless destruction as long as the nonspoliating party provides additional evidence that the inference is more likely to restore than disrupt adversarial balance.

4. There Is No Minimum Culpability Requirement. The framework adopts, in part, the strict liability approach proposed by some commentators by permitting the issuance of a spoliation inference even when the spoliating party is innocent. The inference, when properly understood, should not be employed as a means of punishment or deterrence; it is an imprecise and unwieldy tool for these purposes. Because the spoliation inference is fundamentally distinct from judicial responses that attempt to punish or deter, the availability of the inference should not hinge solely upon the culpability of the spoliator. Even if evidence is spoliated innocently, the inference instruction should be issued if the nonspoliating party offers circumstantial evidence that the contents of the spoliated evidence were adverse to the spoliator.

\section{CONCLUSION}

The spoliation inference has become a valuable, arguably indispensable, tool for courts to employ to rectify the destruction, mutilation, alteration, or concealment of relevant evidence. As the American justice system acknowledges the regrettable prevalence of spoliation in modern-day litigation, the victims of spoliation will pursue a more refined understanding of the prerequisites for this evidentiary sanction. Consequently, courts must strive to establish requirements for the spoliation inference that ensure that the inference will 
satisfy its primary remedial purpose-to restore adversarial balance by leveling the playing field between spoliator and nonspoliator.

This Note has illuminated the disagreement across jurisdictions regarding the culpability and circumstantial evidence requirements for the spoliation inference, and has proposed a framework that courts can employ to ensure that the spoliation inference serves its purpose. The culpability and circumstantial evidence requirements should work together to provide adequate assurance that the spoliation inference will have a tendency to restore and not disrupt the adversarial balance. In crafting a framework for evaluating the suitability of a spoliation inference, courts should recognize this fundamental connection between the culpability requirement and the circumstantial evidence requirement, and employ the framework developed in this Note to govern the consideration of a spoliation inference jury instruction. 